\title{
Microstructural Changes in Sol-Gel Derived Silica Gel Monolith with Heating as Revealed by the Crack Formation on Immersion in Water
}

\author{
Tatsuhiko ADACHI* and Sumio SAKKA \\ (Institute for Chemical Research, Kyoto University, Gokasho, Uji-shi, Kyoto \\ * Ube-Nitto Kasei, 579-1, Yabuta, Gifu-shi, Gifu 500 \\ $611)$

\section{ゾルゲル法で合成したシリカゲルモノリスの微細構造の加熱変化： 水中浸漬時のき裂の生成に基づく検討} \\ 足立龍彦*・作花済夫 \\ 京都大学化学研究所, 611 京都府宇治市五ヶ庄 \\ * 宇部日東化成 $($ 株), 500 岐阜市藪田 579-1
}

\begin{abstract}
The dried silica gel monolith with micropores of about $160 \AA$ in the average diameter, prepared by the sol-gel method from the $\mathrm{Si}\left(\mathrm{OCH}_{3}\right)_{4}-\mathrm{H}_{2} \mathrm{O}-\mathrm{CH}_{3} \mathrm{OH}-\left(\mathrm{CH}_{3}\right)_{2} \mathrm{NCHO}-\mathrm{NH}_{4} \mathrm{OH}$ solution, has been tested for the crack formation on immersion in water after heating to various temperatures up to $1030^{\circ} \mathrm{C}$. A few cracks occurred in as-dried gel before heating, while severe fine cracks were observed in the gels heated to $500^{\circ}$ or $700^{\circ} \mathrm{C}$. A rise in heating temperature up to $850^{\circ}$ or $900^{\circ} \mathrm{Cresulted} \mathrm{in} \mathrm{gels} \mathrm{with} \mathrm{no} \mathrm{cracks,}$ while a few cracks occurred on heating to $1000^{\circ}$ or $1020^{\circ} \mathrm{C}$. No crack was observed when the gel was converted to glass with no open pores by heating to $1030^{\circ} \mathrm{C}$. The occurrence and the degree of severity of crack formation have been discussed on the basis of the change of the size of fine pores, and the strength of silica skeleton with heating temperature.
\end{abstract}

[Received October 14, 1988; Accepted December 15, 1988]

Key-words : Silica gel monolith, Immersion in water, Crack formation, Pore diameter, Strength of silica skeleton

\section{Introduction}

A dried silica gel monolith prepared by the sol-gel method is porous and contains continuous pores. Accordingly, the silica gel monolith as dried and heated to various temperatures can be expected to be used as porous material for filtration of gases and liquids and immobilization of catalysts and enzymes. In order to use the porous material for these purposes, the microstructure and the interactions with solvents have to be known. A marked consequence of the interaction of the brittle porous materials with solvents is the occurrence of cracks and fracture. It is known that the porous silica glasses prepared from alkali borosilicate glasses by utilizing their phase separation easily undergo fracture or crack formation on contacting water, alcohols or other organic solvents. We have made similar observation on the as-dried gel prepared from the $\mathrm{Si}\left(\mathrm{OCH}_{3}\right)_{4}-\mathrm{H}_{2} \mathrm{O}-\mathrm{CH}_{3} \mathrm{OH}-\left(\mathrm{CH}_{3}\right)_{2} \mathrm{NCHO}-\mathrm{NH}_{4} \mathrm{OH}$ solution by the sol-gel process. ${ }^{12}$ Contacting of the gel with liquids of lower surface tensions such as methanol and dimethylformamide produced no cracks, whereas liquids of higher surface tensions, such as formamide and water caused cracks or fracture.

In this work, the porous silica gel monolith prepared by the sol-gel method has been tested for the crack formation on immersion in water after being heated to various temperatures, in order to investigate the interaction of the gel with water, a solvent. It is expected that this observation reflects the change of pore structure and the silica skeleton in the silica gel with heat treatment.

\section{Experimental procedure}

\subsection{Preparation of gel sample}

Dried silica gel monolith was prepared using the solution of the composition $1 \mathrm{Si}\left(\mathrm{OCH}_{3}\right)_{4}$. $1\left(\mathrm{CH}_{3}\right)_{2} \mathrm{NCHO} \cdot 2 \quad \mathrm{CH}_{3} \mathrm{OH} \cdot 12 \quad \mathrm{H}_{2} \mathrm{O} \cdot 5 \times 10^{-4}$ $\mathrm{NH}_{4} \mathrm{OH}$. ${ }^{1)}$ One mole $(148.8 \mathrm{ml})$ of tetramethoxysilane (TMOS) was mixed with one mole of dimethylformamide (DMF) and two moles of methanol to make a solution. A given amount of ammonia water was dropped onto this solution at $50^{\circ} \mathrm{C}$ under stirring. The solution was then cooled to $30^{\circ} \mathrm{C}$, placed in a polytetrafluoroethylene ( Teflon ${ }^{\circledR}$ ) cylinder of $315 \mathrm{~mm}$ long and $49 \mathrm{~mm}$ in inner diameter and sealed with aluminum foil. The solution was gelled by keeping in an oven at 
$30^{\circ} \mathrm{C}$. After keeping at $30^{\circ} \mathrm{C}$ for $24 \mathrm{~h}$, the gel was aged by increasing the temperature from $30^{\circ}$ to $70^{\circ} \mathrm{C}$ in $24 \mathrm{~h}$. At $70^{\circ} \mathrm{C}$, the drying of the gel was started by perforating the aluminum foil with 15 pinholes of $1 \mathrm{~mm}$ in diameter. The temperature was raised from $70^{\circ}$ to $160^{\circ} \mathrm{C}$ in 9 days and kept at $160^{\circ} \mathrm{C}$ for $24 \mathrm{~h}$. The dried gel cylinder thus prepared appears opalescent and is $120 \mathrm{~mm}$ long and $32 \mathrm{~mm}$ in diameter.

Discs of $8 \mathrm{~mm}$ in thickness and $32 \mathrm{~mm}$ in diameter have been cut from the dried gel cylinder and used for the experiment of immersion in water. The heat treatment was made by heating up to a given temperature followed by $1 \mathrm{~h}$ heating at that temperature.

\section{2 Immersion in water}

Immersion experiment was made by placing the disc sample in the water in a petri dish at $20^{\circ} \mathrm{C}$. The hight of water was adjusted to the half of the thickness of the disc, and then the disc was immersed in the water so that the water might have been absorbed from one of the surfaces of the disc. The immersion of the whole disc in water might lead to crack formation due to gases in pores compressed by the intrusion of water from both surfaces of the disc.

\subsection{Characterization of micropores and trimethylsilylation}

The pore size distribution was measured with a Micromeritics Company model AccuSorb 2100 E surface measurement meter. The average pore size was estimated from the pore size distribution curve derived from the adsorption isotherm for nitrogen gas.

The bulk density was measured from the weight and size of the perfectly cubic gel cut from the disc. The porosity was calculated from the bulk density with the assumption that the silica skeleton in the gel has the same density as the silica glass.

For the gel heated to $500^{\circ} \mathrm{C}$, it was attempted to study the effect of the modification of micropore surface on the crack formation in the immersion experiment. The modification was made by replacing hydrophilic hydroxyl groups by hydrophobic trimethylsilyl groups. For trimethylsilylation, the mixture containing hexamethyldisiloxane, trimethylchlorosilane and 2-propanol in the volume ratio of $9: 5: 1$ was used. The gel sample heated to $500^{\circ} \mathrm{C}$ was suspended by a wire above the mixture in the beaker with cover. The whole ensemble was heated at $40^{\circ} \mathrm{C}$ so that the trimethylsilylating vapor could be well incorporated into micropores of the gel.

\section{4 Vickers hardness}

The Vickers hardness of gels was measured with an Akashi Manufacturing Company type MVK-E microhardness tester. In the measurement, the load was changed between $20 \mathrm{~g}$ and $100 \mathrm{~g}$ with the hardness value, and the loading time was kept constant at $10 \mathrm{~s}$.

\section{Results}

The photographs which reveal the appearance of the gels after immersion in water are shown in Fig. 1. Only a small number of large cracks occur in as-dried gel, while numerous fine cracks are produced in the gels heated to $500^{\circ}$ and $700^{\circ} \mathrm{C}$. It is understood that the occurrence of large number of fine cracks corresponds to the more severe stresses than a small number of large cracks. It is seen that no cracks are formed in the samples heated to $850^{\circ}$ and $900^{\circ} \mathrm{C}$, whereas heating to higher temperatures of $1000^{\circ}$ and $1020^{\circ} \mathrm{C}$ causes a small number of cracks again. On heating at $1030^{\circ} \mathrm{C}$ the sample is transparent and appears silica glass and no cracks are seen.

The gel trimethylsilylated after heating to $500^{\circ} \mathrm{C}$ was opaque as shown in Fig. 1, which remained opaque after being immersed in water. The gel before trimethylsilylation underwent the severe crack formation on immersion in water, while almost no cracks were formed after trimethylsilylation.

Figure 2 shows the pore size distribution curves of the gels heated to the given temperatures. Heating to temperatures lower than $900^{\circ} \mathrm{C}$ does not reduce the average pore size, that is, the average pore size remains almost constant at $160 \AA$, which is the value for the as-dried gel. The reduction of the average pore size is noticed only when the heating temperature is $900^{\circ} \mathrm{C}$. It is a little smaller at $140 \mathrm{~A}$. When the gel is heated at temperatures higher than $900^{\circ} \mathrm{C}$, the average pore size becomes increasingly small with rising heating temperature. Heating at $1000^{\circ}$ and $1020^{\circ} \mathrm{C}$ gives the average pore diameter of 110 and $100 \AA$, respectively. It should be noted that the gel heated to $1030^{\circ} \mathrm{C}$ has almost no open pores.

Figure 3 shows the bulk density and Vickers hardness of the gels as functions of heating temperature. Both bulk density and Vickers hardness do not show any noticeable increase, while heating at higher temperatures than $950^{\circ} \mathrm{C}$ results in rapid increase in both values.

Table 1 summarizes the state of crack formation, average pore diameter, porosity estimated from the bulk density and Vickers hardness of the gels heated to various given temperatures. The values have been taken from the figures already shown. 


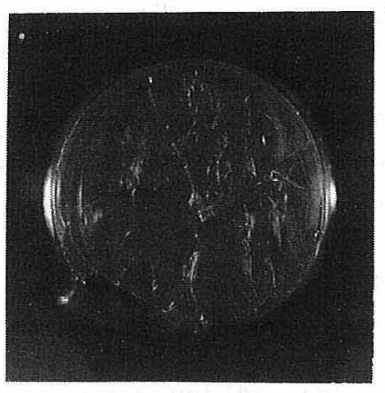

Dried gel

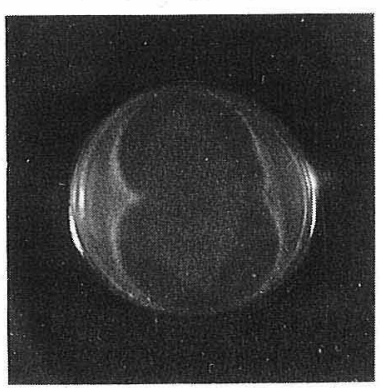

Heated to $850^{\circ} \mathrm{C}$

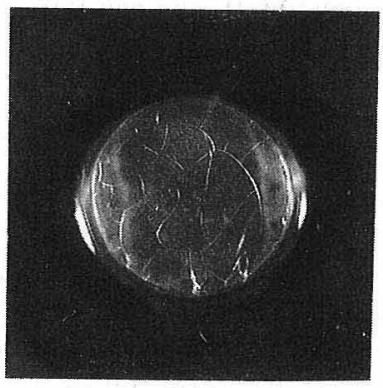

Heated to $1000^{\circ} \mathrm{C}$

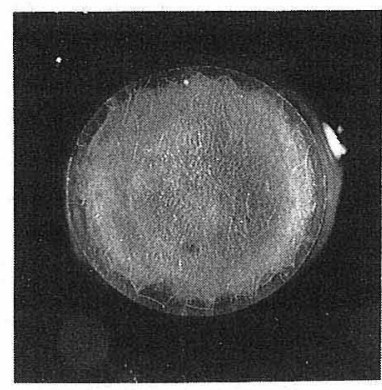

Heated to $500^{\circ} \mathrm{C}$

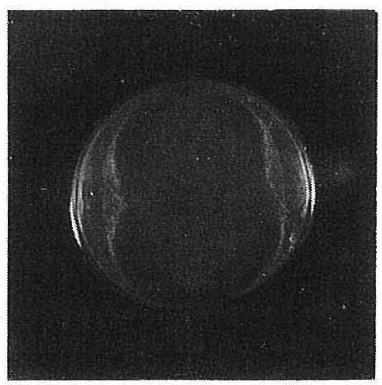

Heated to $900^{\circ} \mathrm{C}$

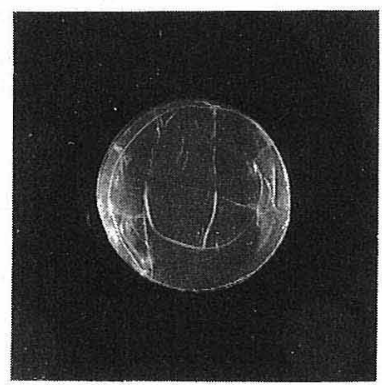

Heated to $1020^{\circ} \mathrm{C}$

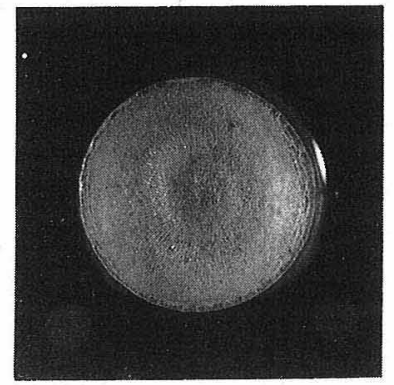

Heated to $700^{\circ} \mathrm{C}$

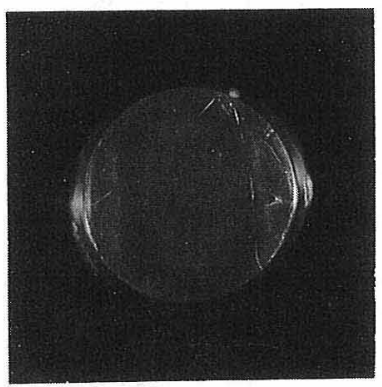

Heated to $950^{\circ} \mathrm{C}$

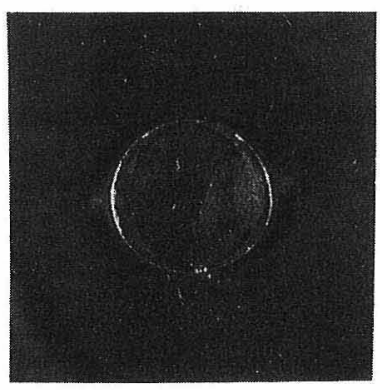

Heated to $1030^{\circ} \mathrm{C}$

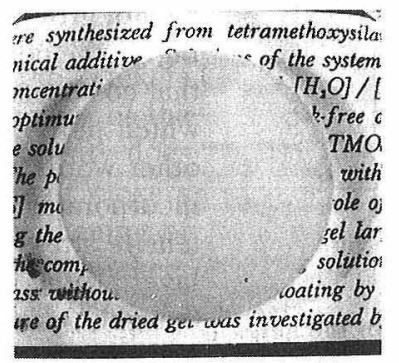

Trimethylsilylated after heating to $500^{\circ} \mathrm{C}$

Fig. 1. Photographs showing the crack formation in gels on immersion in water after heating to various temperatures. 


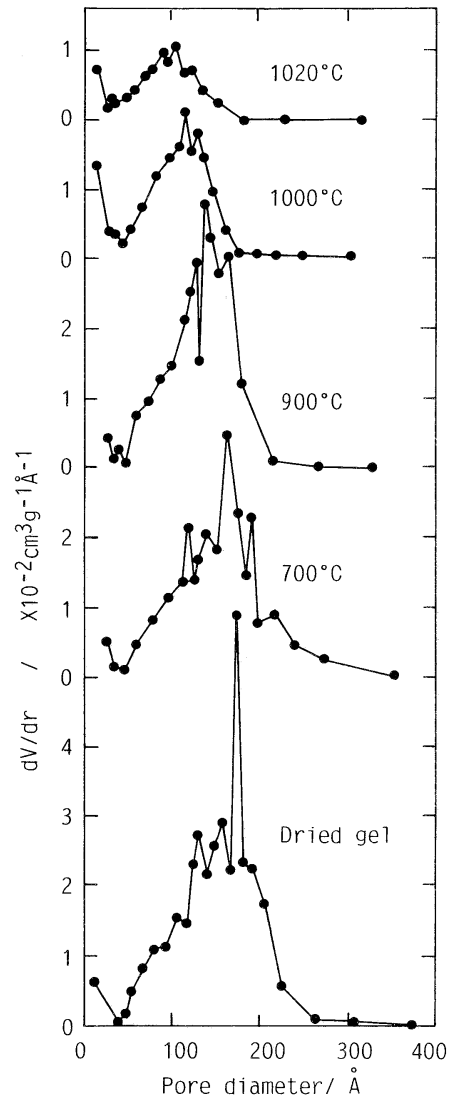

Fig. 2. Pore size distribution in the gels heated to various temperatures.

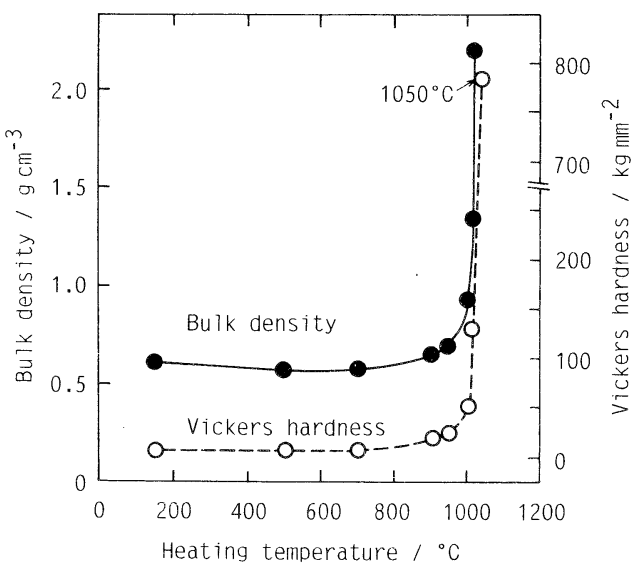

Fig. 3. Bulk density and Vickers hardness of the gels as a function of heating temperature.

\section{Discussion}

\section{1 Occurrence of cracks on immersion in water}

The occurrence of cracks in as-dried gel and some of the heated gels on immersion in water is attributed to the stress produced by the capillary
Table 1. Crack formation, pore diameter, porosity and Vickers hardness in silica gels heated to various temperatures.

\begin{tabular}{llccc}
\hline $\begin{array}{l}\text { Heating } \\
\text { temperature } \\
\left({ }^{\circ} \mathrm{C}\right)\end{array}$ & $\begin{array}{l}\text { Crack formation } \\
\text { in the gel }\end{array}$ & $\begin{array}{c}\text { Average pore } \\
\text { diameter } \\
(\AA)\end{array}$ & $\begin{array}{c}\text { Porosity } \\
(\%)\end{array}$ & $\begin{array}{c}\text { Vickers } \\
\text { nardness } \\
\left(\mathrm{kg} / \mathrm{mm}^{2}\right)\end{array}$ \\
\hline $\begin{array}{c}\text { Dried ge1 } \\
500\end{array}$ & $\begin{array}{l}\text { A few cracks } \\
\text { of fine cracks }\end{array}$ & 160 & 72.6 & 8 \\
700 & $\begin{array}{l}\text { A large number } \\
\text { of fine cracks }\end{array}$ & 160 & 74.1 & 8 \\
850 & $\begin{array}{l}\text { No crack } \\
900\end{array}$ & - & - & - \\
950 & No crack & 140 & 71.0 & 18 \\
1000 & A few cracks & - & - & 21 \\
1020 & A few cracks & 110 & 58.6 & 50 \\
1030 & No crack & 100 & 38.9 & 131 \\
\hline
\end{tabular}

force based on the surface tension of water in micropores. The change of degree of severity of cracks with heating temperature can be explained by the change of the pore diameter and the strength of silica skeleton in the gel with heating temperature.

Assuming that micropores are represented by capillary tubes of diameter $D$, the capillary force $\Delta P$, exerting on the capillary walls at the menisci is expressed by formula $(1) .{ }^{2), 3)}$

$$
\Delta P=\frac{4 \gamma \cos \theta}{D}
$$

where $\gamma$ is the surface tension of the liquid filling micropores, $\theta$ is the contact angle between the liquid and the wall of micropores (silica skeleton in the present case) and $D$ is the pore diameter. Formula ( 1 ) indicates that when the contact angle is constant, $\Delta P$ increases in an inverse proportion to the pore size. The gels used in this study consist of siloxane bondings with some silanol groups and so get wet with water. Accordingly, the pore walls are hydrophilic. This means that $\cos \theta>0$ and $\Delta P$ in formula ( 1 ) is the force which pulls the pore wall towards the liquid. In other words, the surface layer in which water is incorporated tends to shrink and undergoes a tensile stress from the inside beneath the surface layer. If the tensile stress exceeds the strength of the gel, cracks would be produced.

Although we have no precise information on the change of $\cos \theta$ with heat treatment of the gel, $\cos \theta$ may be a measure that indicates whether the pore wall is hydrophobic $(\cos \theta<0)$ or hydrophilic $(\cos \theta>0)$, which is related with the occurrence of cracks. For $\cos \theta<0$, the capillary force pushes pore walls outwards, causing compressive stress in the layer penetrated by water, and no fracture takes place. This explains the reason 
why fine severe cracks are formed in the gel heated to $500^{\circ} \mathrm{C}$ on immersion in water, while no cracks are formed in the same gel after trimethylsilylation. The trimethylsilylation changes the hydrophilic pore surfaces of as-heated gel to hydrophobic, and the stress produced in the surface layer becomes compressive.

It is also noted that for $\cos \theta>0$ (hydrophilic pore walls), the tensile stress induced in the surface layer changes with the value of $\cos \theta$; the stress increases and the tendency towards crack formation increases with decreasing $\theta$.

\subsection{The degree of crack formation as a function of heating temperature}

It has been shown that a small number of large cracks are formed in as-dried gel, while gels heated to $500^{\circ}$ and $700^{\circ} \mathrm{C}$ suffer from a very large number of fine cracks. This suggests that the stress in the heated gels is larger than that produced in as-dried gel. The high capillary force in the heated gel is attributed to a smaller $\theta$. It is possible that in as-dried gel, the pore wall retains a small amount of organic residues, which makes the pore walls less hydrophilic and the $\cos \theta$ smaller, while after heating at $500^{\circ}$ and $700^{\circ} \mathrm{C}$ these organic materials are replaced by silanol or siloxane bonds which makes the pore walls more hydrophilic and the $\cos \theta$ and accordingly $\Delta P$ larger.

The immersion into water did not cause any cracks in gels heated to $850^{\circ}$ and $900^{\circ} \mathrm{C}$, although the average pore size decreased a little, which means an increase in the capillary $\Delta P$. No crack formation can be explained by assuming that heating at $850^{\circ}$ and $900^{\circ} \mathrm{C}$ strengthens the silica skeleton forming capillary walls in such a degree that its strength overcomes the capillary force. A considerable increase in the strength of the silica skeleton can be expected from the temperature dependance of Vickers hardness around these temperatures. It is assumed that the Vickers hardness largely depends on the porosity of the gel. Around $900^{\circ} \mathrm{C}$, however, the porosity does not change so much, and so the change of Vickers hardness has to be attributed to strengthening of the silica skeleton. The increase of the Vickers hardness by two times (from $8 \mathrm{~kg} / \mathrm{mm}^{2}$ to $\left.18 \mathrm{~kg} / \mathrm{mm}^{2}\right)$ is assumed to indicate the strengthen- ing of the silica skeleton.

Cracks are observed again when the gel is heated at $1000^{\circ}$ and $1020^{\circ} \mathrm{C}$. Considering that the pore diameter is small at 110 and $100 \AA$, respectively, compared with those for the samples heated to lower temperatures, the increase in $\Delta P$ is assumed to be larger than that of the strength of silica skeleton.

No open pore is found when the gel is heated at $1030^{\circ} \mathrm{C}$, and it is expected that no crack is formed on immersion in water.

\section{Conclusion}

The silica dried gel monoliths were prepared from $\mathrm{Si}\left(\mathrm{OCH}_{3}\right)_{4}-\mathrm{H}_{2} \mathrm{O}-\mathrm{CH}_{3} \mathrm{OH}-\left(\mathrm{CH}_{3}\right)_{2} \mathrm{NCHO}-$ $\mathrm{NH}_{4} \mathrm{OH}$ solution by the sol-gel method. The gels, heated to various temperatures up to $1030^{\circ} \mathrm{C}$, were tested on the crack formation on immersion in water and the following conclusions were obtained.

(1) When the gel is heated at temperatures lower than $700^{\circ} \mathrm{C}$, there is no change in the pore size and the pore surface becomes more hydrophilic, which causes severe cracks on immersion the gel in water.

(2) Heating at $850^{\circ}$ or $900^{\circ} \mathrm{C}$ increases the strength of silica skeleton which prevents the occurrence of cracks.

( 3 ) In gels heated to $1000^{\circ}$ and $1020^{\circ} \mathrm{C}$, the pore diameter becomes considerably smaller and the resulting increase in capillary force exceeds the increase in the strength of the silica skeleton, which produces cracks in the heated gel.

(4) On heating the gel to $1030^{\circ} \mathrm{C}$, open pores disappear and no crack formation takes place in the sample immersed in water.

Acknowledgements This work was supported by a Grant-inAid for Scientific Research on Priority Areas, New Functionality Materials-Design, Preparation and Control, the Ministry of Education, Science and Culture (62604011).

\section{References}

1) T. Adachi and S. Sakka, J. Non-Cryst. Solids, 99, 118-28 (1988).

2) J. Zarzycki, "Glass Science and Technology", Vol.2, Edited by D. R. Uhlmann and C.J. Kreidl, Academic Press (1984) pp. 209-49.

3) G. W. Scherer, J. Non-Cryst. Solids, 87, 199-225 (1986). 